\title{
Sustaining the productivity of New Zealand's hill country - A land manager's view
}

\author{
D. CAMERON \\ Greater Wellington Regional Council, PO Box 41, Masterton 5840, New Zealand \\ David.Cameron@gw.govt.nz
}

\section{Key message summary}

- Farm plans have been an integral part of assisting landowners to manage eroding hill country in the Wellington region

- Land Use Capability (LUC) mapping is a key tool in prioritising investment in erosion control and land development programmes

- Improving pasture production and management on LUC Class 6 land provides a great opportunity in sustain the productivity of our hill country

- Alternatives land uses such as forestry and manuka can provide increased returns from marginal pasture land.

\section{Introduction}

Hill country in New Zealand is defined as land with slopes above $15^{\circ}$ and located below an altitude of $1000 \mathrm{~m}$ a.s.1. Under this definition 37\% (10 million ha) of New Zealand's total land area is classified as hill country, with the majority (6.3 million ha) located in the North Island. Since the 1950s Catchment Boards, and more latterly Regional Councils and Unitary Authorities have a statutory obligation to manage the effects of land use on the environment. This responsibility has predominantly focussed on managing the effects of hill country soil erosion through a variety of mechanisms, including farm planning, catchment schemes, financial incentives, advice, and information. In the Wairarapa, pastoral hill country covers 268595 ha (33\% of the region). Erosion-prone land within the pastoral hill country covers 103850 ha $(12.8 \%$ of the region) and the sustainable management of this class of land has been a focus for land management advisors. A standard farm plan approach has been used to effect behaviour change and enabled a number of land management tools to be used to enhance economic and environmental performance. This approach offers insight into techniques and tools that can be used build resilience into hill country farming, and ultimately the communities that support them. The issue of climate change and the likelihood of more intense rainfall events and widespread droughts loom large over hill country communities. Adapting to these changes will be vital to the long term sustainable use of New Zealand's hill country.

\section{Provision of farm plans}

Farm planning as a tool for addressing soil erosion issues on farms and within catchments was first prescribed in New Zealand in the Soil Conservation and Rivers Control Act 1941. This gave rise to the 11 Catchment Boards and 6 Authorities or Commissions across the country and the mandate to work with landowners and catchment communities on the management of onsite and off-site effects of soil erosion. Through the National Water and Soil Authority a soil conservation grants programme was initiated. This recognised the national benefit of this work and farm plan grants rose to the giddy heights of $66 \%-75 \%$. Landowners provided the balance. In 1989 around 850 single and multi-purpose local bodies (including Catchment Boards) were consolidated into 86 multi-purpose local authorities, including regional councils with broad environmental responsibilities. In the 1990s various Regional Councils and Unitary Authorities abandoned the concept of farm planning. The Wellington Regional Council (WRC) was one who introduced regional grants to replace those national grants previously administered by the Wairarapa Catchment Board. Regional grant rates fell to $40 \%$, with landowners providing $60 \%$ of the funding for qualifying works. Despite this drop in grant rate, uptake of new plans and implementation of soil conservation works programmes continued. Following the Manawatu floods of 2004 the Ministry of Primary Industries (MPI) established the Hill Country Erosion Fund (HCEF) to assist regional councils in their funding of priority works. This has provided a much needed boost to the WRC land management programmes. The cornerstone of this programme in the Wellington region is the commitment and support

Table 1 Number of hill country properties in the Wellington region that have an approved farm plan, and the decades in which they were approved.

1950 to 19591960 to $1969 \quad 1970$ to $1979 \quad 1980$ to $1989 \quad 1990$ to 19992000 to 20092010 to now

\begin{tabular}{lllllll}
\hline Farm plans prepared & 78 & 118 & 156 & 104 & 34
\end{tabular}


provided by landowners. This is a trusted long-term partnership where accountability and service delivery are key factors.

A total of 527 farm plans have been prepared across the Wellington region since the 1950 s, with $99 \%$ of these located in the Wairarapa (Table 1). Data in Table 1 reflects the considerable influence of the national grants programme for farm plans which was abolished in 1989. The increase in new farm plans since 2010 largely reflects the impact of MPI funding for the Wellington Regional Erosion Control Initiative (WRECI) programme. Since the 1950s a large number of properties have been converted to forestry, amalgamated with neighbouring properties or subdivided into lifestyle blocks. Today it is estimated that there are 400 hill country properties in the Wairarapa that contain erosion prone land, and 324 (or $81 \%$ ) currently have a farm plan (Table 2).

\section{Classifying hill country}

In classifying hill country the most used tool is the Land Use Capability (LUC) system. The system was developed to assist the sustainable management of land and used at a scale of 1:50 000. The LUC Class provides an assessment of the lands capability for sustained primary production, taking into account its physical limitation and its versatility. The land is classified into eight classes, with Class 1 being elite/versatile land with no limitations to long term sustainable use, and Class 8 land being unsuitable for primary production. Within these various LUC Units the land requires similar management and conservation treatment, and is suitable for the same kind of crops, pasture or forestry species, with similar potential yields. The New Zealand Land Resource Inventory (LRI) and the associated LUC database includes estimates of the potential stock carrying capacity across the country, from this the annual dry matter production can be estimated. For the last fifteen years, WRC has been providing detailed 1:10 000 LUC Class maps as part of its Farm Plan resource information. Additionally, it has established more accurate pasture yields for each unit. This has enabled much improved decision making around key aspects of hill country management, including erosion management, land development, soil management and pasture development.

On average $70 \%$ of hill country properties in the Wairarapa contain erosion prone land (Class 6 and 7). Conversely the area of flat productive land (Class 1, 2 and 3 ) is $14 \%$ or approximately 100 hectares (Table 3 ).

\section{Improving hill country pasture production}

In the Wairarapa large areas of hill country pastures have been raised from un-improved to semi-improved or even improved yields by aerial oversowing, topdressing and subdivision from 1945 to the present. As an example, Table 4 records the estimated yield ranges for Class $6 \mathrm{e} 3$, which is a class of easy hill country land derived from mudstone with a mean annual rainfall of $1100 \mathrm{~mm}$.

While hill country by definition covers Class 5, 6 , 7 and 8 lands, it is Class 6 land that offers the greatest potential for productivity increases. This land is less steep than Class 7, is less prone to soil loss from erosion, and where pastures are improved this land supports

Table 2 Extent of farm plans in the Wellington region.

\begin{tabular}{ccccc}
\hline $\begin{array}{c}\text { Total hill } \\
\text { country farms }\end{array}$ & $\begin{array}{c}\text { Farms with } \\
\text { a farm plan }\end{array}$ & $\begin{array}{c}\text { Area of } \\
\text { eroding land (ha) }\end{array}$ & $\begin{array}{c}\text { Area of eroding land } \\
\text { with a farm plan (ha) }\end{array}$ & $\begin{array}{c}\text { Percentage of eroding } \\
\text { land with a farm plan }\end{array}$ \\
\hline$\sim 400$ & 324 & 103850 & 80899 & 77.9 \\
\hline
\end{tabular}

Table 3 Average size for a Wairarapa hill country property and the mix of each LUC Classes (mapped at 1:10 000).

\begin{tabular}{ccccc}
\hline LUC class & $\begin{array}{c}\text { Area (ha) of each LUC class for all } \\
\text { hill country farm plans }(\mathbf{n = 3 2 4 )}\end{array}$ & $\begin{array}{c}\text { Area (ha) of each LUC class } \\
\text { on an average farm }\end{array}$ & $\begin{array}{c}\text { Percentage of each LUC class } \\
\text { (scale 1:10 000) }\end{array}$ \\
\hline 1 & 83 & $<1$ & $<0.1$ \\
2 & 6398 & 21 & 3 \\
3 & 24210 & 78 & 6 \\
4 & 14705 & 42 & 9 \\
5 & 21292 & 63 & 42 \\
6 & 95923 & 296 & 28 \\
7 & 63103 & 197 & 1 \\
\hline
\end{tabular}


stock carrying capacities in the order of 13.3-16.7 su/ ha. Soil conservation plantings of space planted poplars and willows at spacing's of $12-15 \mathrm{~m}$ are appropriate to provide the necessary erosion control.

Table 5 shows that dry matter yields from Class $6 \mathrm{e} 8$ are increased in the presence of appropriate soil conservation plantings. In effect, less land is lost to erosion in the presence of soil conservation plantings thereby improving overall dry matter yields. This is not the case with Class 7 land and alternative uses need to be considered.

\section{Providing alternative land uses \\ Farm scale conservation woodlots}

Farm conservation woodlots have long been used to manage soil loss from highly erodible sites, generally Class 7 land. Primarily this has involved Pinus radiata because of the ability to realise an economic return from the woodlot. Traditionally these were small areas on a farm, ranging in size from 5-20 ha. In recent times, Regional Councils such as Horizons Regional Council (HRC) servicing the Manawatu and Wanganui areas has adopted innovative approaches such as joint ventures or forestry rights to effect land use change on much larger areas of eroding land. This has also been in partnership with the MPI through the HCEF. The HCEF now supports five similar regional initiatives in the North Island including Wellington, Taranaki, Northland, Hawkes Bay and Waikato. In addition the East Coast district has its own East Coast Forestry Project (ECFP). The returns from conservation woodlots are low in comparison with large forestry

Table 4 Pasture yields for LUC Class 6e3 - Wairarapa.

\begin{tabular}{lrr}
\hline Pasture type & \multicolumn{1}{c}{$\begin{array}{c}\text { Yield } \\
\text { (kg DM/ha/year) }\end{array}$} & $\begin{array}{r}\text { Stock } \\
\text { Units/ha }\end{array}$ \\
\hline Unimproved pasture & $3100-6300$ & $4.1-8.4$ \\
Semi-improved pasture & $6300-10000$ & $8.4-13.3$ \\
Improved pasture & $10000-12500$ & $13.3-16.7$ \\
\hline
\end{tabular}

Table 5 Loss of pasture yield averted by spaced planting of conservation trees on Class $6 \mathrm{e} 8$.

\begin{tabular}{lcc}
\hline $\begin{array}{l}\text { Pasture types on } \\
\text { LUC Class 6e8 }\end{array}$ & $\begin{array}{c}\text { Yield } \\
\text { (kg DM/ha/year) }\end{array}$ & $\begin{array}{c}\text { Yield } \\
\text { (kg DM/ha/year) - } \\
\text { in the presence of } \\
\text { soil conservation } \\
\text { plantings }\end{array}$ \\
\hline Unimproved pasture & $2200-4300$ & $2200-4500$ \\
Semi-improved pasture & $4300-6900$ & $4500-7100$ \\
Improved pasture & $6900-8600$ & $7100-8900$ \\
\hline
\end{tabular}

ventures because of the limitations of scale, the remote locations of the woodlots and the effects of eroding land on the quality of the trees. However, the returns exceed those of livestock enterprises, particularly on the Class 7 land because the land often has a carrying capacity of 4-6 su/ha.

\section{Manuka/kanuka for honey production}

Manuka and to a lesser extent kanuka are becoming more widespread as land use change options. Recent studies have concluded that manuka and kanuka increase slope stability by modifying the soil moisture regime. In particular, the relationship between storm interception loss and rainfall for kanuka are comparable across vegetation communities including manuka, various forms of beech forest and Pinus radiata. A small number of manuka/kanuka trees have been studied to determine the morphology and distribution of roots that are shallow and penetrate to depths of 2-2.5 m. However, kanuka root-wood has a greater live tensile strength and a slower decay rate than many other tree species, both exotics and indigenous. This suggests that the level of reinforcement provided by young dense stands is substantial on steep slopes that would otherwise be susceptible to shallow translational landslides. In natural manuka scrub, one beehive/ha is the norm, typically producing $30 \mathrm{~kg}$ of honey per hive, though the variation can be large. The hope is that selected lines of manuka with high floral density and known high Unique Manuka Factor (UMF®) content will remove that variability and consistently yield more honey of higher value. Currently, landowners might get $10-15 \%$ of a $\$ 400 /$ ha revenue from hives in natural manuka scrub. In a plantation situation where high UMF tree stocks are planted the revenue could be raised to a $30 \%$ revenue share. Given the landowners' investment in trees, it should be $30 \%$ of much higher revenue, perhaps as much as $\$ 1100 /$ ha, or a $6-14 \%$ marginal return on land that would otherwise have been a cost to the farm and an erosion threat to the receiving environment.

\section{Issues to be addressed}

Lack of maintenance in soil conservation plantings

Soil conservation plantings include poplar and willow poles spaced across eroding pasture land, and conservation woodlots where land is 'retired' from grazing. Farm conservation woodlots has long been used to manage soil loss from highly erodible sites, generally Class $7 \mathrm{e}$ land where erosion (e) is the major limiting factor to long term sustainable use. Conservation woodlots have generally been planted in Pinus radiata because of the opportunity for commercial return. Many of these woodlots have been managed to produce pruned logs to enhance 
their commercial returns. The story is much different for conservation plantings of space planted poplar and willows. While there are multiple uses for these plantings such as shelter, timber, fodder and bees, it has been estimated that $90 \%$ remain unmanaged. In the Wairarapa, approximately $15 \%$ of the annual plantings $(\sim 25000)$ will be form-pruned to ensure leader dominance in the emerging tree. A further 5\% will be topped at a height of $1.8 \mathrm{~m}$ to produce fodder as a risk management strategy for drought management. In the not too distant future a large investment will be required to manage aging poplar and willow trees on hill country landscapes. Agreements with Regional Councils currently do not cover maintenance or replacement of these trees.

\section{Opportunities}

\section{More detailed land classification mapping}

The national LRI and the associated LUC database are mapped at 1:50 000 which are too generalised for application at detailed farm scales. More detailed mapping at the farm scale (i.e 1:10 000 or better), provides an opportunity to deconstruct the LUC Units into their component classifications. For example, the Class 6e2 Unit used in the Southern Hawkes Bay and Wairarapa regional classification, is described as moderately steep to strongly rolling, fertile mudstone and siltstone hill country in higher rainfall areas with moderate potential for shallow earth-flow erosion. Strongly rolling landforms are not distinguished from the moderately steep landforms at the regional scale. However, at the farm scale, the strongly rolling landforms are of sufficient size and extent to be mapped separately. They are less susceptible to erosion and can, therefore, be managed differently. If this is extrapolated across all Class 6 landforms the productivity improvements would be large.

Improved pasture/grazing management of LUC Class 5 and easy LUC Class 6 land

The identification of more productive Class 5 and Class 6 land from a detailed farm map offers opportunity for improving pasture species and management. While much of the gain is from subdivision, fertiliser and management, recent advances in the use of annual clovers on dry Wairarapa hill country points the way for improving the overall productivity across a high proportion of the average farm. Additionally the tap root length of some of the annual clovers are upwards of $25 \mathrm{~cm}$ and will also have a positive effect on reducing shallow forms of slip erosion.

\section{Increased soil conservation plantings across the} better LUC Class 6 land

The use of farm conservation woodlots has long been used to manage soil loss from highly erodible sites, generally Class 7 . The predominant method is to establish some form of afforestation either with closed canopy exotics or natural reversion. Pole planting using poplars and willows is often difficult to establish and survival rates are often insufficient to provide enough stability to reduce sediment reaching waterways. A mosaic of land use is most desirable, where the most sustainable soil erosion measure matches the land class. The Class 6 land by virtue of its easier slope, less erosion, deeper soils and greater spatial representation provides the best opportunity for the increasing productivity. On the other hand, Class 7 land where the onsite and offsite effects of soil erosion are greatest is often marginally economic in a pastoral sense. In various scenarios considered during the preparation of many farm plans the stock displaced by afforestation or reversion can be absorbed within the business by improved management of better classes of land. Class 6 land well planted with poplars and willows should be considered for this role.

\section{Securing long term stakeholder funding for management of hill country erosion}

The securing of long term stakeholder funding is absolutely critical to the success of soil erosion programmes. The results in the Wairarapa are testament to this. The current hill country programme has largely been in place for nearly 65 years. It is likely to take at least thirty more. Close to one 100 years of joint effort between taxpayers, ratepayers and landowners. It is my view that this tripartite approach genuinely reflects the benefits that accrue at the national, regional and local level. It is evident that landowners have fully committed to the programme and only in the hardest of economic times does the investment reduce. In the Wairarapa the WRECI hill country erosion programme is strongly imbedded in the community. In recent years the model used so effectively in the hill country has found similar favour with landowners farming intensively in the Wairarapa valley. This programme has a focus on nutrient management. The nature of the relationship in both the hill country and intensive land use programmes enables a wide range of other, often related resource management issues to be discussed, such as biodiversity management, soil management and effluent management.

\section{Conclusion}

In an age where climate change is signalling more droughts and more frequent high intensity storms the productivity of New Zealand's hill country will come under intense pressure. Hill country farmers have exhibited an ability to adapt well to external influences over a long time. Crucial to this over the coming years 
will be a better understanding of the capability and versatility of various land classes, ongoing support from central and local government for erosion control programmes, research and development investment to identify new or improved pasture species, and options for alternative land uses such as forestry and manuka honey. The use of farm plans as a tool for the improved management of erosion-prone land in the
Wellington region has met with considerable success over many decades. However, the greatest advantage of the farm plan has been as a vehicle to establish trusted partnerships with landowners, partnerships that have an ability to engage in much wider resource management and farm management discussions. This approach assists in building resilience to the business in a nonregulatory environment. 
